\title{
Christian Higher Education in Europe: A Historical Analysis
}

\author{
D. W. Bebbington \\ Professor of History, University of Stirling
}

The subject of this paper is a very broad one, the history of the universities of Europe as a whole. Its particular theme is the place of Christianity in higher education. For ease of analysis, the material is examined in terms of seven eras. Although there was considerable overlap between the phases, they do reflect significant and largely distinctive periods in university history.

The first corresponded to the rise of scholasticism in the twelfth and thirteenth centuries and extended into the fourteenth. The earliest European university in the north developed from the cathedral school of Paris in the twelfth century, the label 'scholasticism' deriving from its origins. The initial tradition in university history can therefore claim Christian roots. Oxford emerged during the later twelfth century to become a fully fledged institution at the beginning of the following century. It grew in that particular town rather than elsewhere because of the large number of clergy resident there. The university was modelled on Paris, though less closely than was once supposed. Cambridge arose in 1209 following the death of two Oxford students in a characteristic affray between town and gown. Others fled for safety to what Oxford scholars regarded as an obscure Fenland town. Down to the mid-fourteenth century, only those three universities - Paris, Oxford and Cambridge - held general European recognition for their degrees in arts and theology. 
What were the early universities like? They were highly clerical institutions. Students all wore the tonsure, ensuring good business for local barbers. Each university was an integral part of the church. Paris was under the authority of the city's bishop, whose chancellor actively directed the university. Oxford, though more independent, owed allegiance to the Bishop of Lincoln. When Queen's College, Oxford, was founded in 1341 , it was supposed to possess thirteen chaplains. ${ }^{1}$

The curriculum in the 'liberal arts' derived from ancient Rome. The first stage, or trivium, consisted of grammar, rhetoric and logic, the basic skills of self-expression. The second stage, or quadrivium, included arithmetic, geometry, astronomy and music. After graduating in arts, a student could proceed to one of the three higher faculties, which were theology, law or medicine.

The papacy encouraged the growth of Paris in particular. The members of the university there could help to define agreed doctrines, as they did, for instance, over the nature of the eucharist. It was through the efforts of Paris scholars that it was possible to promulgate the doctrine of transubstantiation at the fourth Lateran Council of 1215. Universities helped create uniformity of belief in mediaeval society.

The teachings of Aristotle, however, were infiltrating western Europe through Arabic texts and commentators. The new learning troubled many, as is vividly portrayed in Umberto Eco's novel, The Name of the Rose. There resulted a tension with the 
received worldview drawn primarily from the thought of Augustine. It was the achievement of Thomas Aquinas, the most learned of the scholarly Dominicans, to integrate Aristotle with scripture. In that form a legacy of scholasticism was bequeathed to subsequent generations. Yet disputes continued, especially between Dominicans and Franciscans. The result was a creative interaction in which uniformity of credal expression became impossible.

Debate was often vigorous. In the 1190s at Oxford a lecturer on the Psalms criticised 'students in theology who refrain from preaching the word of the Lord while roaring in disputation all the day long, ${ }^{2}-$ a phenomenon not unknown in later years. The criticism itself shows laudable Christian priorities. So does the career of Robert Grosseteste, Chancellor of Oxford and then Bishop of Lincoln, who died in 1253 . He told Oxford instructors that the Bible should be their only text book and that it should be taught in the morning when minds were fresh. ${ }^{3}$ This was an era when Christianity was dominant in the universities.

The second phase may be characterised as the era of civil law in the fourteenth and fifteenth centuries. Before passing on to that period, however, a southern European prelude needs to be noted. At Salerno from at least the eleventh century medicine had been studied at a high level. The city was a health resort, and so medical expertise readily flourished there. At Bologna from the late twelfth century higher studies of law emerged. Municipalities such as Bologna maintained the practice of Roman law from ancient times, and so its teaching was a natural development. 
These southern universities were very different from their northern counterparts. They were immediately practical in their concerns, possessing no arts or theology faculties until Bologna added them in the mid-fourteenth century. They were lay organisations, though not anti-clerical, as they have sometimes been portrayed. Students were laymen, and so were their teachers, who were paid by the city councils. The institutions were broadly democratic, with students' guilds electing their instructors. Student power was a reality. The Italian model was copied elsewhere, notably in Spain.

The same note of practicality increasingly affected the northern universities. There was pressure from rulers, both popes and kings, for a supply of civil servants. The favoured studies were therefore canon law, the code of the church, and civil law, the system inherited from ancient Rome. From as early as the 1230 s there were many more lawyers than theologians at Oxford. Their numbers continued to increase down to around 1500. Civilians specialising in Roman law were usually more numerous than canonists because they were more directly useful to secular rulers. A letter of 1321 from an Oxford doctor of civil law at Avignon to a doctor of theology at home is revealing. He urges his friend to come to share in the academic pickings of the papal service. ${ }^{4}$ Other rulers and municipalities realised the value of trained civil servants. Hence between 1300 and 1425 no fewer than thirty-two new universities were created. ${ }^{5}$

They did not, however, cease to be essentially Christian in tone. Theology remained a major subject, churchmen thronged to the northern universities and colleges 
were founded as Christian communities. Increasingly, however, a student went to university with the aim of securing a good job afterwards. Christianity was therefore less central to the raison d'être of the universities. If Christianity still enjoyed a hegemony, for most participants in academic life the faith had become more of a means to an end and less of an end in itself.

In the third era, the sixteenth and early seventeenth centuries, Renaissance humanism flourished. Humanism had grown up in Italy from the thirteenth century, but at first it remained largely outside the universities. It entered the curriculum in many parts of Europe only during the fifteenth century. The new approach did not supplant Aristotle, whose teaching was still the basis of metaphysics. Scholasticism long remained an intellectual force, even after the triumph of the Reformation in northern Europe.

What humanism did was to add a fresh dimension to university studies. It must not be seen as a form of anti-Christian secularity, man-centred rather than God-centred. Rather it was the exploration of the ancient classics from the original texts. Grammar, poetry, history, moral philosophy and, above all, rhetoric, the art of persuasion, were the chief humanist fields. The 'professor of humanity' at Scottish universities has traditionally been the holder of the chair of Latin. Renaissance humanism was entirely compatible with the Christian faith. Its greatest exponent was Erasmus of Rotterdam, who produced an accurate version of the Greek text of the New Testament in 1516. 
Humanism was disseminated through an expansion of the universities. There were three main driving forces behind the growth of higher education at this epoch. Wealth came to Europe, especially in the form of gold from the New World. Far more people could afford academic study, particularly in gold-rich Spain. Seventeen extra universities were founded in Castile alone between 1474 and $1620 .^{6}$ By the early seventeenth century Spain was the best educated country in Europe. Another factor was the demand from the lay aristocracy for a university training, especially in the later sixteenth century. The Renaissance ideal of an omnicompetent gentleman embraced learning as well as more muscular qualities. By 1600 the English universities included approximately equal numbers of aspiring clergy and landowners intending to return to their estates. ${ }^{7}$ The other factor was the religious division of the sixteenth century. The Reformation and the Counter-Reformation alike created a desire to instil sound principles into the population. An educated clergy was the essential method, and universities supplied much of the training.

It was an era when classical thought was integrated with little discrimination into the inherited Christian worldview. The figures from pagan mythology in John Milton's religious verse, for instance, often appear strangely anomalous. Yet Christianity continued in high esteem in the university world. Professorial salaries at the University of Copenhagen in the later sixteenth century form a good illustration: for philosophy 80 thalers, law 100 and medicine 140 , but for theology $150 .^{8}$ Theologians evidently enjoyed the most prestige. A motto scribbled by another humanist in a book by Erasmus sums up part of the temper of the age: ad docendum a precibus ('we must turn to teaching only 
after our prayers'). ${ }^{9}$ Despite the sometimes peculiar assimilation of ancient thought, vital Christianity was evident in the universities.

The later seventeenth and eighteenth centuries, however, formed a period of decay. In this fourth era many universities still existed. Indeed their very number was a dimension of the problem, since few could be large enough for efficiency. Each petty German state had to possess its own university. In many institutions there could be little intellectual stimulus, and the number of attenders fell throughout Europe. In 1740 the University of Avila in Spain, admittedly an extreme example, had only five students. ${ }^{10}$ In England and elsewhere, the poor were squeezed out. Universities were designed for the leisured, and so settled, for the most part, into languid ways. In some other places, including much of Germany, the aristocracy deserted the universities. In Russia the nobility did not even start to come. The first Russian university, established at Moscow in 1755 , had only plebeian students down to the 1830 s. ${ }^{11}$ Such institutions, lacking standing in society, were outside the mainstream of national life.

There were other symptoms of decay. The defence of legal privileges became a leading preoccupation and perquisites for kin and schoolfellows were jealously guarded. Medicine was at a low ebb, its study being so abstract that there was little concern with actual healing. Medical schools trained young men, according to a cynical official in Hanover in about 1730, 'so that people may be buried methodically'. ${ }^{2}$ And Latin often remained the medium of instruction, surviving as the language prescribed for doctoral dissertations at Copenhagen until as late as $1879 .^{13}$ 
Alternative institutions were both a cause and an effect of this state of affairs. The Jesuits had entered higher education in force, providing what was wanted by the elites of France, Spain, the south German lands and elsewhere, sometimes within universities but often outside. Academies sprang up to discover new knowledge and to give it a more practical bent. The example of Louis XIV's academy was followed in Prussia, Dissenting academies flourished in England and by the late eighteenth century even the small towns of Scotland were establishing their own miniature versions. Here the curriculum was normally up-to-date, and it is significant that the English Independent theologian Philip Doddridge abandoned teaching in Latin at his Northampton Academy from 1729. ${ }^{14}$ Much of the vigour in higher education flowed in new channels.

Universities nevertheless remained, in many respects, distinctly Christian. At Salamanca in the 1750 s nearly half the students were members of religious orders. ${ }^{15}$ Universities continued to defend the confessional position of their states. They were bastions of faith, albeit decaying bastions. Christianity was formally dominant, but vitality had often fled from their gates.

The fifth phase, beginning in the eighteenth century and growing in the nineteenth, was the era of Enlightenment. Intellectual stirrings in the eighteenth century tended to exalt the power of reason. The methods of Cartesian philosophy and then of Newtonian science were applied in a wider range of fields. With the intellectual triumphs of Sir Isaac Newton, experimental science gained unprecedented esteem. Systematic 
investigation, it was held, would bring new light, which would eventually spread from the thinkers to the masses. Life would improve if only dated institutions were reformed. The idea of progress was born. Universities would participate in the march of mind if they discovered new truths, served a social purpose and became altogether more utilitarian.

In this body of thought there was commonly a secularising tendency. If reason were upgraded, religion might be downgraded. Unfettered investigation fostered by the tolerant philosophy of John Locke could lead to criticism of Christianity. Institutional religion could appear, as it did to Voltaire, an obstacle to enlightenment. Hence anticlerical campaigns were launched in various universities, especially in Roman Catholic countries. Their particular target was the Jesuits, who were to be suppressed by the pope in 1773. Christian influence was by no means eclipsed, for much was undertaken in the spirit of Catholic reform. Yet in Austria and Spain, the universities were turned from the 1760s into secular organisations producing civil servants.

The most drastic change came in France, where the Enlightenment had taken its most irreligious guise. The French Revolution led to the abolition of universities as Roman Catholic institutions in the years 1791-93. In their place separate faculties were set up over succeeding years, each concerned with a single subject - law, navigation, astronomy and so on. State education as a whole was deeply influenced by the positivism of Auguste Comte, what Catholics often condemned as 'materialism'. It was not until 1875 that Catholics were allowed their own institutions of higher education, and then only with restrictions. In 1900 there were about 27,000 students in state universities, but 
a mere 1,200 in Catholic institutions. ${ }^{16}$ Similarly in Italy, in the secular enthusiasm of the Risorgimento, theology faculties were abolished in 1872 and universities became bulwarks of positivism. The only knowledge, it was held, comes through natural senses; nothing can be supernatural - the attitudes of the Italian anticlerical Settembrini in Thomas Mann’s Magic Mountain. Christian higher education was marginalised.

The Enlightenment, however, followed a very different course in northern Europe, expressing itself as far less of an anti-religious force. In Scotland, which possessed five universities while England had only two, the Enlightenment was welcomed and blended with Presbyterian religion. William Robertson, the Principal of the University of Edinburgh and historian of America, was a minister of the 'Moderate' school that prided itself on its appreciation of new learning. In England, University College, London, was founded in 1828 with a utilitarian bent, and at the ancient universities, with the abolition of the requirement of celibacy for college fellowships, these posts ceased to be staging posts for clergy in quest of permanent livings. The changes of the nineteenth century at Oxford and Cambridge were secularising, at least in the sense that the colleges ceased to be Anglican preserves. But the same developments were designed to allow opportunities to Dissenters, Baptists included, at the ancient universities. So they were by no means wholly subversive of the Christian character of higher education.

Consequently the era of the Enlightenment and its diffusion was ambiguous. The alterations in higher education tended to dilute or eliminate the religious tone of the 
universities, but change roused them from their earlier lethargy. The secularising effects were felt strongly in southern Europe, but more mildly and gradually in the north - and there a substantial Christian legacy remained.

The sixth phase can be called the age of neo-humanism and, though overlapping with the previous era, it can be dated to the nineteenth century and on into the twentieth. It was marked by a scholarly tradition that emerged in Germany as an alternative to the Enlightenment, and was associated with Romanticism as a broad cultural movement. Its roots were in earlier universities that had adopted progressive programmes, especially Halle (1694) and Göttingen (1737), but its flowering was at the University of Berlin (1810), created by Wilhelm von Humboldt as a Prussian think-tank to roll back the intellectual tide of French influence deriving from the Revolution and Napoleon. Berlin became the model of neo-humanism.

Its guiding principle can best be appreciated as a reaction against the enthronement of reason by the French Enlightenment. In its place there was a greater appreciation of the place of will and the emotions in human affairs. In metaphysics there was a stronger sense of the spiritual, though leading thinkers championed not so much Christian orthodoxy as a misty religiosity. There was a marked pantheistic tendency in German poets such as Friedrich von Schiller. In epistemology, the theory of knowledge, it was believed that the mind apprehends by intuition rather than by induction. Yet because the world embodies the divine, careful investigation is called for. German universities promoted research seminars such as that of Leopold von Ranke in history. In 
the prevailing theory of history of the times, it was characteristic for the ideal to be located not in the future, to be attained by human progress, but in the past. There was a powerful sense that human existence is lived out in the flux of history. Berlin, for example, produced the historical school of law that glorified the customary legal practices of Germany that had existed down the ages.

Such principles were widely held in universities where traditional arts faculties had come to concentrate on philosophy. Following G. W. F Hegel, who taught at Berlin from 1818 to 1831 , idealistic philosophy was in vogue. Theology was demoted so that philosophy could become 'queen of the sciences'. Furthermore, the utilitarian dimension of higher education was reinforced. Because the state was heavily involved in German universities, the practical side of instruction was not neglected. Technical colleges proliferated in the later nineteenth century.

The German model was widely imitated, particularly after the Prussian victories over Austria in 1866 and France in 1870. Eight new universities were established on the new pattern in Hungary and the Balkans between 1860 and $1914 .^{17}$ The German approach was praised in Britain by Matthew Arnold. It was imitated in America, for example by the introduction of Ph.D.s by research. The neo-humanist vision brought new vitality to universities. On the other hand it tended to dissipate the Christian content of university life, particularly through undue reverence for a style of theory associated with Romanticism that tended to erode the doctrinal content of the historic faith. 
Seventhly, there was the state of affairs in the later twentieth century and at the beginning of the twenty-first. The legacy of the Enlightement and of neo-humanism remained powerful, but, partly because there were two conflicting sources of inspiration, there was no single understanding of the nature and purpose of a university that commanded general assent. There were also fresh cultural currents, originating in the early twentieth-century school of thought often labelled 'Modernism' that fed into the later phenomenon of Postmodernism. Cultural Modernism in this sense is to be distinguished from theological Modernism, which was contemporary but largely unrelated. Postmodernism should be seen not as a reaction against cultural Modernism but as a revolt against the Modernity associated with the Enlightenment. Postmodernism repudiates the dominance of reason and scientific method, not the cultural innovations of the early twentieth century.

This complex body of thought was originally most evident in literature and the arts, in each of which there was a break with Romanticism in the years around 1900. Strongly shaped by Freud, Jung and depth psychology, a characteristic expression of the new movement was Surrealism. The most potent influence over the novel cultural idiom, however, was Friedrich Nietzsche, with his teaching that there is no God and consequently no order in the universe. Language has no fixed relationship to reality, but can be used arbitrarily. The debt to this mode of thinking is evident in recent theorists such as Jacques Derrida, the inspiration for the technique of deconstruction in literature. Postmodernism has no epistemology, since, it holds, there is nothing to know except flux. 
This school of thought therefore offers no fresh justification for the university's traditional quest for knowledge.

The vacuum in agreed views of the purpose of universities has been filled by demands for 'relevance' to immediate concerns. Radicals in the 1960s called for studies to be relevant to changing society. The fragmentation of the University of Paris following the student riots of 1968, its splitting into numerous separate universities, symbolises the disintegration of a unified quest for knowledge. In Italy the state's response to student demands was even more disastrous. Without expanding institutional provision, the government opened access to the universities to vast extra numbers. By the late 1970s the Italian universities were in chaos. In the Communist states of eastern Europe relevance of a different kind was required. The state insisted that higher education must be shaped by the imperative of national economic development. Accordingly student numbers mushroomed: between 1937 and 1965 they increased by 500 per cent. $^{18}$

In western Europe from the 1980s the cry was raised - in Germany as much as in Mrs Thatcher's Britain - that higher education should be made more relevant to business. Government spokespeople were heard declaring that universities do not exist to discover or transmit knowledge for its own sake. The threat to university education passed from disruptive elements within to state pressure from without. Resistance to the clamour for relevance was enfeebled by the absence of any consensus about the purpose of a university. Where there is no vision, the university perishes. 
A conclusion to be drawn from this survey is that higher education cannot be isolated. The university is part of its environment, political, economic, social and cultural, and so is unavoidably affected by its context. It is not to be expected that separate Christian institutions could remain untainted by the world. That principle is well illustrated by the history of St Peter's College, Oxford. Opened as a hall for Evangelical Anglican undergraduates in 1928, it retained a distinctive ethos for some time. Its master was still an Evangelical Christian in the 1960s. Steadily, however, it became more like other colleges, so that virtually nothing is distinctive now. In the perennial tension between Christianity and its context, the destiny of institutions cannot be determined by religion to the exclusion of the setting.

What is needed in the early twenty-first century is a Christian appreciation of the rising pattern of thinking that is cast in the Postmodernist mode. The encounter must be critical, for Christianity is not to be translated without remainder into a Postmodernist idiom. Rather, contemporary intellectual approaches such as Jungian analysis or Nietzschean philosophy can be chosen for comparison with gospel principles. Any common ground that is discovered can become an avenue for Christianity to permeate the secular learning of the day. Likewise Derrida, for all his apparent obfuscation, is not to be rejected out of hand, but evaluated from a Christian point of view. Such a method restores the faith to a significant role within the whole range of university studies. To engage with contemporary culture from the standpoint of historic orthodoxy was the method of C. S. Lewis in an earlier generation, and his technique can well be imitated in our own. 
A second conclusion is that, notwithstanding the reservations already made, Christianity can be integrated into the system of higher education. The assimilation has never, even in the earliest era of university history, generated a form of institution that can be labelled wholly Christian, but the influence of the faith has often been more widely felt than it is now. Two thinkers who have considered the relationship between faith and higher studies call for particular attention.

One is John Henry Newman, later the cardinal, the author of The Idea of a University. At Oxford Newman had led the Tractarian movement in the Church of England during the 1830s. His conversion to the Roman Catholic Church in 1845 meant departure from Oxford, a deprivation he felt acutely. When, in the early 1850s, he was involved in a scheme for a Catholic university in Dublin, his thinking, expounded in the book, partly reflected the Oxford he had loved.

A university, Newman contended, exists 'to teach universal knowledge'. ${ }^{19}$ That terse statement contains a wealth of implications. A university, on this understanding, is designed primarily to teach, that is to train undergraduates. Its chief purpose is not research, an aim that was rated more highly in the Enlightenment and neo-humanist traditions. The knowledge, furthermore, is universal, in that no branch of learning is to be excluded. Theology, Newman concludes, is to form part of the curriculum, and all studies are to be related to God. Knowledge, rather than behaviour, he also holds, is to form the content of the teaching. The university's raison d'etre is not instruction in morals. Rather, the culture of the intellect is to produce gentlemen, people with mental 
poise and the ability to grasp the underlying principles of any activity. Newman's ideal was to have persistent appeal, and his book is still an unsurpassed text on university theory. It is the natural starting point for contemporary discussion of the purpose of higher education. In any quest for consensus on the purpose of a university in the modern world, Newman must have his place. Because it is so firmly grounded on theological premises, The Idea of a University ensures that at least one of the voices in the debate is Christian.

Another thinker worthy of careful study is Sir Walter Moberly. His book The Crisis in the University was published by the Student Christian Movement Press in 1949. ${ }^{20}$ The son of an Anglican clergyman, Moberly held posts in five British universities before, in 1935, becoming Chairman of the University Grants Committee, a body which distributed government funds to higher education. His work reflected more general thinking at the time, drawing on a series of pamphlets and a conference of Christian academics. It was part of the atmosphere of post-war reconstruction, and was to influence the Robbins Report on Higher Education of 1964 and the new British universities that were created in its wake.

The analysis in Moberly's book is still valuable as a study of how faith should be related to publicly supported higher education. It considers a range of contemporary problems in the academic world of which the chief is an unwillingness to ask fundamental questions about nature and purpose. It is in fact a powerful indictment of some of the characteristic weaknesses that were to mar the seventh era of university 
history as identified here, the position failing to reach any shared understanding of higher education that persists in the twenty-first century. Spurious remedies for the crisis in university values are rejected. Scientific humanism, an ideology traced to Francis Bacon and Karl Marx, is dismissed as too shallow to be a foundation for academic activity. That is to repudiate the prescriptions of the Enlightenment (the Baconian model) and of neohumanism of a radical kind (the Marxist view), understandings deriving from the fifth and sixth phases of university history. Classical humanism is found equally wanting. It is located as an undiscriminating appeal to the ancients such as was common during the third and fourth eras, and it is a will-o'-the-wisp.

Moberly is just as decisive, however, in refusing to heed the cry, 'Back to the Christian Tradition'. It is no solution, he argues, for Christianity to dominate all studies, as was the case in the first period of university history in northern Europe. This superficially attractive solution is turned down as impractical. Christians today, Moberly remarks, are the peculiar people, so that their faith cannot be made the capstone of education for all. This proposed solution is also inequitable, for it is unfair to other intellectual positions held in good conscience. Moreover it would be disastrous for Christianity. The Christian religion would be diluted and distorted for other ends: Moberly has in mind the anti-Communism of his day. He is unequivocal in rejecting the use of Christianity for other purposes such as took place in the second era, when rulers exploited the later mediaeval universities as a source of legally trained civil servants. Although the past can inform proposals for the present day, we can agree with Moberly, no period in the past provides a blueprint for the university of his day or ours. 
The impracticality of any proposal to turn the generality of universities in Europe into professedly Christian institutions is even more apparent now than in Moberly's time. The prestige of pluralism, endorsed by the state for the sake of inter-communal harmony, is unprecedentedly high. That makes his solution to the conundrum of relating Christianity to the university even more worthy of notice. The central proposal of Moberly's work is that the university should constitute an open forum for the debate of ultimate issues. Christian scholars should play a full, but never exclusive, part in discussion. In a pattern of true pluralism, he holds, Christianity will show its superiority. Sir Walter Moberly's vision seems judicious and fundamentally right. The Christian religion, according to his prescription, should contribute its wisdom to the common stock of the university. He offers the modern world an attractive mode of integrating the faith into higher education. The history of European universities suggests that, though that task cannot be performed perfectly, it can be done better than it is at present.

\footnotetext{
${ }^{1}$ J. R. L. Highfield, 'The Early Colleges', in J. I. Catto (ed.), The History of the University of Oxford: 1. The Early Oxford Schools (Oxford: Clarendon Press, 1984), p. 251.

${ }^{2}$ R. W. Southern, 'From Schools to University', in Catto (ed.), University of Oxford, p. 23.

${ }^{3}$ M. W. Sheeham, 'The Religious Orders, 1220-1370', in Catto (ed.), University of Oxford, p. 197.

${ }^{4}$ R. W. Southern, 'The Changing Role of Universities in Mediaeval Europe', Historical Research, 60 (1987).

${ }^{5}$ E. J. M. van Eijl, 'The Foundation of the University of Louvain', in J. Ijsewijn and J. Paquet, The Universities in the Late Middle Ages (Leuven: Leuven University Press, 1978), p. 29.

${ }^{6}$ R. L. Kagan, 'Universities in Castile, 1500-1810', in L. Stone (ed.), The University in Society (Princeton: Princeton University Press, 1974), vol. 2, p. 357.

${ }^{7}$ L. Stone, 'The Size and Composition of the Oxford Student Body, 1580-1910', in Stone (ed.), University in Society, vol. 1, p. 72.

${ }^{8}$ S. E. Stybe, Copenhagen University: Five Hundred Years of Science and Scholarship (Copenhagen: Royal Danish Ministry of Foreign Affairs, n.d.), p. 37.

${ }^{9}$ Marginal note by Nicholas Udall in D. Erasmus, Epistolae ... ad Diversos ...(Basle: J. Frobenius, 1521), in Keynes Collection, King's College, Cambridge.

${ }^{10}$ Kagan, 'Universities in Castile', in Stone (ed.), University in Society, vol. 2, p. 393

${ }^{11}$ R. Pipes, Russia under the Old Regime (London: Weidenfeld and Nicolson, 1974), p. 263.
} 
${ }^{12}$ C. E. McClelland, State, Society and University in Germany, 1700-1914 (Cambridge: Cambridge University Press, 1980), p. 30.

${ }^{13}$ Stybe, Copenhagen University, p. 110.

${ }^{14}$ A. V. Murray, 'Doddridge and Education', in G. F. Nuttall (ed.), Philip Doddridge, 1702-51: His Contribution to English Religion (London: Independent Press, 1951), p. 114.

${ }^{15}$ Kagan, 'Universities in Castile', in Stone (ed.), University in Society, vol. 2, p. 391.

${ }^{16}$ C. S. Phillips, The Church in France, 1848-1907 (London: SPCK, 1936), p. 198.

${ }^{17}$ R. Okey, Eastern Europe, 1740-1980: Feudalism to Communism (London: Hutchinson, 1982), p. 126.

${ }^{18}$ Okey, Eastern Europe, p. 219.

${ }^{19}$ J. H. Newman, The Idea of a University, ed. I. T. Ker (Oxford: Clarendon Press, 1976), p. 33.

${ }^{20}$ W. H. Moberly, The Crisis in the University (London: SCM Press, 1949). 